Volume 3, Issue 2 (Summer 2011)

\title{
Rembrandt's Gifts: A Case Study of Actor-Network-Theory
}

Michael Zell

Recommended Citation:

Michael Zell, "Rembrandt's Gifts: A Case Study of Actor-Network-Theory," JHNA 3:2 (Summer 2011), DOI: 10.5092/jhna.2011.3.2.2

Available at https://jhna.org/articles/rembrandts-gifts-case-study-actor-network-theory/

Published by Historians of Netherlandish Art: https://hnanews.org/

Republication Guidelines: https://jhna.org/republication-guidelines/

Notes: This PDF is provided for reference purposes only and may not contain all the functionality or features of the original, online publication. This is a revised PDF that may contain different page numbers from the previous version. Use electronic searching to locate passages. This PDF provides paragraph numbers as well as page numbers for citation purposes.

ISSN: 1949-9833 


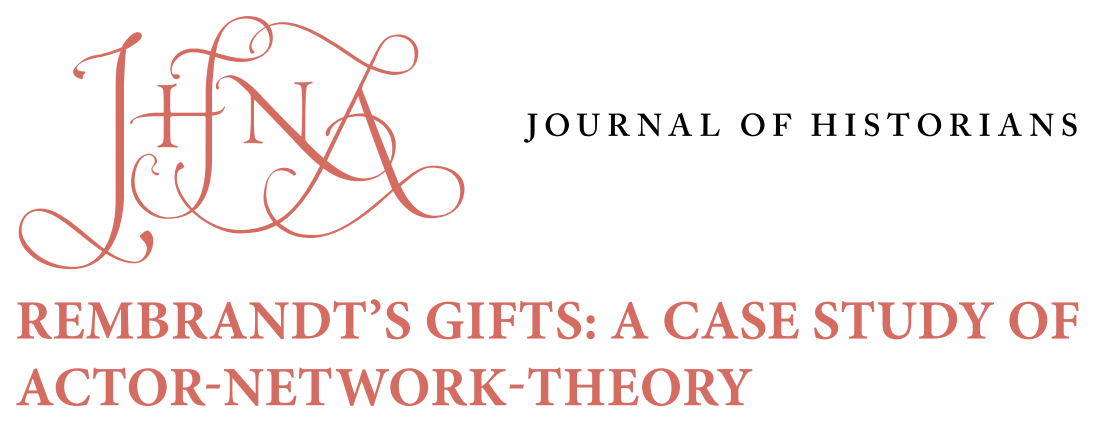

\section{Michael Zell}

This study explores the applicability of Actor-Network-Theory, a recent paradigm of social theory, to the investigation of Rembrandt's relations with patrons and collectors. Known by the acronym ANT, the method privileges objects as critical agents in creating, sustaining, and extending social ties and thus offers a model for capturing the dynamics underlying the interdependencies between Rembrandt, his art, his patrons, and collectors. I focus on Rembrandt's works presented and circulated as gifts, which epitomize the short-lived assemblies between humans and objects that ANT considers the cornerstone of social activity. Drawing on ANT's approach, I highlight the agency of these works in materializing and enhancing the reciprocal ties that bound networks of collectors and liefhebbers together with Rembrandt. D0I 10:5092/ jhna.2011.3.2.2

This study explores the applicability of Actor-Network-Theory, a recent paradigm of social theory, to the investigation of Rembrandt's relations with patrons and collectors. While I make no claim to genuine expertise in Actor-Network-Theory, known by the acronym ANT, the approach seems to me a method of conceptualizing social ties that may offer a productive model for art historians. It must be acknowledged at the outset, though, that its usefulness does not lie in its explanatory value. ANT is not a theoretical framework that can be deployed to explain how social networks operate, let alone illuminate unknown conditions or interactions between Rembrandt and his patrons. (In fact, the founders of ANT adamantly reject the usefulness of framing structures in analyzing social activity). Rather, in my judgment, ANT offers a heuristic model for rendering the dynamics underlying the interdependencies between Rembrandt, his art, his patrons, and collectors. The method is potentially valuable, then, for capturing the coconstructive role of each of these participants in the consolidation of social networks that evolved in the vicinity of Rembrandt's artworks.

Since Rembrandt was a prolific artist who catered simultaneously to a variety of audiences of patrons and collectors, my exploration of ANT necessarily focuses on a discrete category of his art: works presented and circulated in the form of gifts. The advantage of focusing on gift giving, a major research paradigm of anthropology, is that it sheds an intense light on the capacity of art to embody social relations, and thus on the effects that artworks exercise on and through social networks. As we shall see, this brings us to the very core of ANT's theory of how society is constructed. 


\section{Actor-Network-Theory: A Summary}

The central distinguishing feature of Actor-Network-Theory is the role that objects play in its redefinition of the social realm. The method embraces objects as participants or actors in creating, sustaining, and extending social ties, and thus is an effort to overhaul notions of society as being constituted exclusively of human interactions. In his 2005 book Reassembling the Social, Bruno Latour, leading spokesman for ANT, writes that "face-to-face interaction is not a plausible departure point to trace social connections....because they are being constantly interfered with by other agencies." Conversely, as he has elsewhere insisted, "things do not exist without being full of people," and so the study of humans must also entail the study of objects. ${ }^{2}$

ANT thus undertakes to "rescue" objects from the subordinate and passive role typically assigned to them in social theory. Sociology normally imagines, as Latour puts it, an "objectless social world, even though daily routine... [places humans and objects] in constant companionship, continuous intimacy, inveterate contiguity, passionate affairs, and convoluted attachments." ${ }^{3}$ Serving primarily as backdrops for human activity, objects may be seen to reflect, reinforce, objectify, symbolize, or reify what are considered to be more concrete realities, such as power relations, social hierarchies, social or cultural power, or gender relations. But ordinarily in sociology they cannot, as Latour states provocatively, "be at the origin of social activity."

5 ANT's embrace of objects is one important component of a broader project to effect a radical paradigm shift, which is principally a reaction against the traditional conceptions of society that art historians also routinely invoke to explain the social dimension of works of art. Put simply, ANT rejects the idea that social forces or social context shape or determine human interactions. Such terms, according to ANT, are nothing more than labels that evoke invisible entities that in fact do not exist. Society, as Latour insists, does not exist above, below, behind, or in front of us, but as short-lived, heterogeneous networks or associations. Objects enter into ANT's version of society by performing a critical role in mediating these interpersonal relationships. In typically colorful language, Latour writes: "As soon as you believe social aggregates can hold their own being propped up by 'social forces', then objects vanish from view and the magical and tautological force of society is enough to hold every thing together with, literally, no thing." ${ }^{5}$ Objects are thus considered constitutive elements and embodiments of social relations, and focusing on their capacity to exercise agency underscores the practical means used in human ties to create, sustain, and recruit others.

ANT's project of dissolving distinctions between the social and material worlds explicitly rejects empiricism's categorical separation of the facts of matter from mental judgment as an adequate way of accounting for or characterizing experience. ${ }^{6}$ With a newly level playing field between material objects and humans, a "flattened landscape" as Latour calls it, nonhuman entities can begin to assume less narrowly defined roles than in empiricist accounts. Intrinsic to this flattened social landscape is the conviction that the human and material worlds operate not in a dialectical relationship but as a network or aggregate of heterogeneous components. ANT also collapses distinctions drawn between an external social system and an inner world of subjectivity because each is considered to be in constant formation through encounter with the other. As a result, the alternative between an outside world imposing itself on the individual and an individual resisting 
the imposition of outside forces, of externalism versus internalism, is set aside. ${ }^{7}$

7 Art as a class of object also makes an appearance in Actor-Network-Theory. Latour takes issue with critical sociologies of art, such as Pierre Bourdieu's, which conceive of art primarily as an instrument that reflects social distinctions. ${ }^{8} \mathrm{ANT}$, by contrast, takes seriously the passions that art can elicit, rejecting the assumption that such responses must originate in a source outside the artwork itself. Latour's scathing characterization of sociological approaches to art is worth quoting at length:

Apart from religion, no other domain has been more bulldozed to death by critical sociology than the sociology of art. Every sculpture, painting, haute cuisine dish, techno rave, and novel has been explained to nothingness by the social factors "hidden behind" them ... all the objects people have learned to cherish have been replaced by puppets projecting social shadows which are supposed to be the only "true reality" that is "behind" the appreciation of the work of art ... if you are listening to what people are saying, they will explain at length about how and why they are deeply attached, moved, affected by works of art which "make them" feel things. Impossible! Forbidden! To be affected is supposed to be mere affectation. ${ }^{9}$

ANT's solution to this dilemma is to trace the ties that bring together people and objects, following the dynamics that unfold as humans and nonhuman entities interact: as Latour writes, "It is counter intuitive to try to distinguish 'what comes from the object' and 'what comes from viewer' when the obvious response is to 'go with flow'. Object and subject might exist, but everything interesting happens upstream and downstream." ${ }^{10}$

\section{Actor-Network-Theory and Art History: Rembrandt as Case Study}

9 The importance placed on objects in Actor-Network-Theory's version of social theory is presumably intriguing to art historians. Of course, we have always recognized the agency that artworks exercise on people. Art history also already embraces artworks as agents that can shape, rather than merely reflect or reinforce social values or hierarchies. In fact, art historical studies such as Michael Baxandall's now-classic Painting and Experience in Fifteenth-Century Italy have indirectly contributed to the development of ANT's theories through recent sociological studies of taste and music. ${ }^{11}$ Latour also does not acknowledge Alfred Gell's provocative anthropological theory of the agency of art objects. ${ }^{12}$ But in privileging material objects in the establishment and performance of social activity, ANT does offer a new paradigm that allows us to reimagine the social world as being composed of composite networks of relations in which objects, including art works, are critical, mediating agents. The difference is primarily a matter of emphasis. Instead of appealing to an intangible social context to help account for the distinctive physical, formal, or iconographic features of art; instead of relating art and society; or attempting to situate an artwork in its social milieu, we might first construct versions of the social by tracing the interactions that unfold in close proximity to art objects. Art would then emerge as a primary agent in mediating how certain social assemblies were generated, maintained, and extended. Latour, quoting the architect and architectural theorist Rem Koolhaas, goes so far as to exclaim "context stinks"13 because it cannot explain the practical means by which the social is performed and by which it must be continuously negotiated in order for social cohesion or social distinction to be sustained. 
Since objects are essential to this process, artworks would then constitute the very substance of the networks in which they are embedded and from which they are inseparable. Embracing such an approach would reorient art history's preoccupation with the concept of context toward the idea of networks of affiliation mediated by objects. ANT therefore has potentially important implications for the study of art as a constitutive part of how the social is defined.

Broadly speaking, ANT's proposal for reassembling the idea of the social would appear promising for describing some of the structures characteristic of Rembrandt's interrelations with patrons and collectors through the circulation of his artworks. ANT's ideas could provide a set of terms and validation for rendering the artist and his works as coconstructive agents in the performance of the networks that formed around them, simultaneously shaping and being shaped by patrons and collectors. To be sure, information about these individuals is limited, but Rembrandt was clearly at the center of a complex and continually negotiated web of relations, the social dynamics of which challenge prevailing models of artist-patron relationships. ANT, I think, offers a way of overcoming the rivalry between the models of patronage and marketplace that largely dominated and to a certain extent still exert an impact on Rembrandt studies, resulting in accounts that depict him either as a failed painter for patrons or an autonomous agent unbeholden to the tastes and desires of patrons. ${ }^{14}$ Such polarized accounts derive in part from the unsatisfactory alternative Latour decries between the idea of society as a force that determines individual behavior and the notion of individuals as free agents who resist societal pressures to follow their inner convictions. Recent scholarship acknowledges the multivalent nature of Rembrandt's interactions with patrons and clients and thus attempts to move away from such reductionist paradigms. ${ }^{15}$ In modeling a social landscape in which artworks are critical agents embodying and influencing social relations and concepts, ANT could contribute to this reorientation by providing an effective tool for capturing the mutually constitutive character of Rembrandt's highly distinctive artworks-especially, I would argue, his later art-and the patrons and liefhebbers for whom they were created. ${ }^{16}$

\section{Rembrandt and the Symbolic Economy of the Gift}

11 One facet of Rembrandt's career in which I am particularly interested presents a focused and illuminating site for exploring ANT's applicability to the study of his art: Rembrandt's exchanges of art as gifts and the circulation of his artworks in the form of gifts. ${ }^{17}$ Such episodes epitomize the short-lived assemblies between humans and objects that ANT considers the cornerstone of social activity, and focusing on them reveals the means by which certain personal ties between Rembrandt and members of his circle of admirers were created, sustained, and extended. The operations of the symbolic economy of the gift also place an especially intense spotlight on the very role that ANT assigns to objects in mediating and ordering social interactions. ${ }^{18}$ The ethos of the gift sets into motion values of sociability and honor that enclose the donor and receiver in a relationship of reciprocity. In the process, the exchanged object assumes and exercises a distinct aura or agency because it remains inalienable from the donor, continuing to be identified with the transaction itself. The gifted object marks and concretizes the social bond created or reinforced by the circumstances of its transaction. By contrast, when an object is exchanged as a commodity it becomes alienated from the donor by the payment of a purchase price, which usually ends the relation between the two parties. Gift giving, as Marcel Mauss showed in his pioneering study The Gift of 1925 and subsequent anthropologists have refined and elaborated, is a "total social phenomenon." 
12 The ritual exchange of gifts was pervasive in early modern Europe, and vibrant gift economies existed alongside and interacted with commercial markets. ${ }^{19}$ Irma Thoen has shown that the routine exchange of a host of objects and services as gifts permeated seventeenth-century Dutch social life, ${ }^{20}$ and Geert Janssen's study of Willem Frederik of Nassau, stadtholder of Friesland, has demonstrated the vital role that gifts played in the negotiation of both political and familial networks of patronage and clientage. ${ }^{21}$ The presentation of artworks as gifts was also widespread among artists and collectors in the seventeenth century. ${ }^{22}$ The Flemish flower painter and coadjutor (lay brother) of the Jesuit order Daniel Seghers never sold his paintings but made them available to the Society of Jesus to present to rulers and dignitaries, and he received lavish presents from his illustrious patrons in gratitude for his paintings. ${ }^{23}$ The Italian Guido Reni adamantly refused to set prices for his works, insisting they were gifts, not mere commodities. ${ }^{24}$ In the words of his seventeenth-century biographer Carlo Cesare Malvasia, Reni detested "the mention of price in a profession in which, he said, it should be obligatory to negotiate on the basis of an honorarium or a gift." ${ }^{25}$ Patrons were expected to reciprocate with a payment reflecting the high esteem in which Reni was held as well as the patron's own honor as a connoisseur and munificent supporter of the arts.

13 In presenting their works as gifts Rembrandt and his contemporaries sought to mobilize the ideal of valore di stima, an estimation of an artist's stature and his work's value based on reputation and quality, not expenditure of labor. As Eric Jan Sluijter has recently argued, Rembrandt's conduct with patrons-his uncompromising faith in the value of his own worth as an artist and his requests for extraordinarily high remuneration (sometimes even excessive amounts) -indicates that he espoused such an ideal. ${ }^{26}$ That Rembrandt could be obstinate even with important clients has been confirmed again very recently by the discovery of documents from 1666/67 relating to a commission from an Italian nobleman for two altarpieces for a Genoese church. Rembrandt refused to yield to pressure to finish the paintings on schedule, providing as an excuse for an eight-month delay that he was unwilling to rush work to which he had applied himself with "the utmost mental commitment" and for which he hoped "to acquire fame and honor." ${ }^{27}$ Rembrandt clearly used a variety of available methods to market his work and promote his standing as an artist in the various phases of his career. ${ }^{28}$ The ideal of artistic inspiration embodied in the concept of valore di stima, however, underwrote his increasing defiance of the norms of conventional patronage relationships as well as the economics of the open market. In offering his artworks as gifts, Rembrandt was embracing an acknowledged means for an ambitious artist to attempt to transcend both the subservience implied by production on command and the alienation engendered by commercial transactions.

\section{Rembrandt's Gifts to Huygens}

14 Firsthand records of Rembrandt's statements are extremely scarce, but in three of the seven surviving letters by his hand he repeatedly offers his work in the form of gifts. As rare and tantalizing glimpses into Rembrandt's mode of conducting relations with patrons, these gestures are highly significant. The letters date from the 1630s, when he was cultivating aristocratic patronage in The Hague. On January 12, 1639, Rembrandt offered a painting ten feet long and eight feet high as a token of appreciation to Constantijn Huygens, secretary to Prince Frederik Hendrik. ${ }^{29}$ The painting may have been The Blinding of Samson from 1636 (fig. 1), the original dimensions of 
which corresponded to the letter's description. ${ }^{30}$ As head of the secretariat, Huygens was responsible for all the stadtholder's correspondence, functioning essentially as the intermediary through which access to the prince could be attained. In this capacity, he received many letters from artists, authors, and others seeking his help, as well as gifts in various forms. ${ }^{31}$

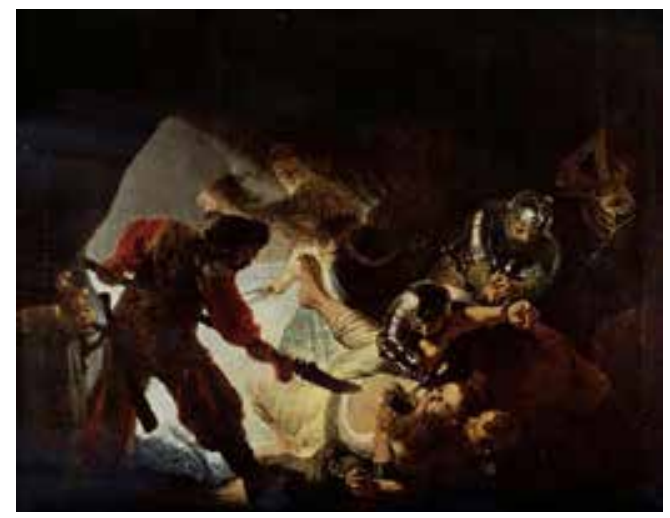

Fig. 1 Rembrandt van Rijn, The Blinding of Samson, 1636, oil on canvas, $206 \times 276 \mathrm{~cm}$. Städelsches Kunstinstitut, Frankfurt, inv. no. 1383 (artwork in the public domain)

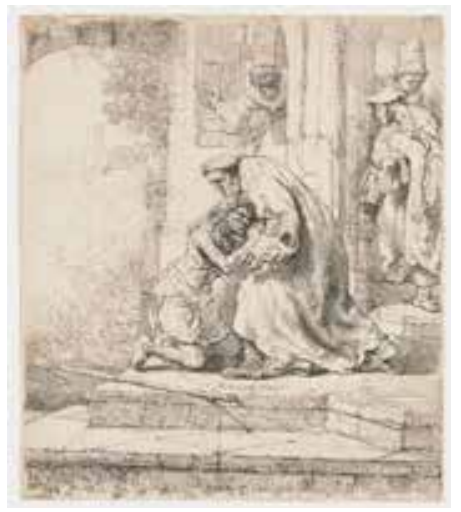

Fig. 2. Rembrandt van Rijn, The Return of the Prodigal Son, 1636, etching, $155 \times 137 \mathrm{~mm}$. Rijksmuseum, Amsterdam, inv. no. RP-P-1961-1039 (@ Photo Rijksmuseum) (artwork in the public domain)

Declaring himself Huygens's "obliging and devoted servant," Rembrandt offered the monumental picture in gratitude for Huygens's role in brokering the prestigious commission for the Passion cycle. ${ }^{32}$ About two weeks later Rembrandt apparently dispatched the extravagant present to The Hague, acknowledging in the accompanying letter that he was doing so because "I feel deeply obliged to requite [you] with service and friendship ... [and] in spite of your wish, [I] am sending [you] along [with this letter] a canvas, hoping that you will accept it, because it is the first memento which I offer you, Sir." ${ }^{33}$ In fact, this was not the first gift of art Rembrandt had presented to Huygens; three years before he had sent the courtier some of his "latest work," presumably impressions of recent etchings like The Return of the Prodigal Son from 1636 (fig. 2), which he described as a "token of my readiness to serve you," adding: "I trust that you will most graciously accept it in addition to my greetings." ${ }^{34}$ Later in February 1639, after the flamboyant painting had been sent and when he was about to receive final payment from the prince, Rembrandt assured Huygens: "I shall forever seek to requite you, Sir, for this reverence, service, and evidence of friendship." 35

16 It is clear that Huygens had originally refused to accept the gift, which Rembrandt acknowledges when he writes that he was sending the accompanying canvas "in spite of your wish." Rembrandt's first payment on his expensive new house on the Breestraat was due, so the gift he insisted upon sending was meant to encourage Huygens to arrange quick reimbursement for the latest Passion pictures. Rembrandt's fawning language in the letters is usually dismissed as empty rhetoric, and much has been made about his "ulterior," self-interested motivation for offering the gift, which is undeniable. ${ }^{36}$ Focusing exclusively on ulterior motives, however, produces an inadequate account of the complex social dynamics involved in the negotiations. Doubtless Rembrandt's offer was understood as a device for accruing financial and social capital; but a taboo on making this underlying motivation explicit was essential to the symbolic value of the exchange. ${ }^{37}$ Rembrandt's professions of affection and devotion, moreover, were determined by the expectations of courtly 
decorum and clientage. Gifts, especially in court settings, were strongly associated with issues of honor, service, and loyalty, and thus drew the receiver into a special bond with the donor. ${ }^{38}$ Rembrandt's spectacular gift, far from merely an overgenerous means of offering thanks, should therefore be understood as his attempt to transform an economic and professional bond with Huygens into a social alliance animated by a set of expectations based on honor, not profit. Thus, if Huygens accepted the gift, he would be expected to reciprocate by continuing to promote Rembrandt's career, to protect him, to embrace and support him as a personal client.

17 If the painting was The Blinding of Samson, the violent subject may have been calculated to appeal to Huygens's personal taste, and to his rank as a courtier. Extravagant gifts typically found favor in court circles, where they tended to be conspicuous, even spectacular objects designed to attract attention and sustain interest. ${ }^{39}$ The forceful and gruesome imagery of the Blinding undoubtedly fulfilled these criteria. Rembrandt's rendering of physical violence in vivid pictorial form still captivates, endowing the painting with a forceful agency that compels and entraps the beholder. As a gift, the work's ability to initiate social agency would have been magnified immeasurably. Even if the proffered work were another painting, though, its sheer scale would have greatly enhanced its ability to act as a mediator of Rembrandt's interests. Hanging in Huygens's palatial new residence on the Plein, its inescapable presence inseparable from Rembrandt's presentation, the canvas would have served as a provocative and intransigent agent of Rembrandt's effort to impose on the stadtholder's secretary an inalienable bond of reciprocal obligations or mutual service. In defying Huygens's refusal of the gift, Rembrandt apparently was banking on his painting's capacity to overcome resistance. ${ }^{40}$

18 Although Huygens was initially reluctant to enter into the complex relationship symbolized and inaugurated by acceptance of Rembrandt's extravagant gift, perhaps he relented, as two more lucrative commissions were forthcoming from the stadtholder: an Adoration of the Shepherds and a lost Circumcision from 1646. Rembrandt would receive 5,400 guilders for the seven paintings that comprise the commission, a large sum consistent with the generous remunerations generally awarded by the prince. It is possible that Huygens's initial resistance was nothing more than a demonstration of the courtesy demanded by the protocols of accepting lavish gifts from clients. ${ }^{41}$ Yet Huygens could have obviated the painting's ability to act as a challenging reminder of his obligations to Rembrandt even if he had accepted it. Jaap van der Veen has recently documented that Joan Huydecoper quickly disposed of a painting of the Entombment that Jan Lievens had given him as a gift after completing a portrait commission in 1659. Huydecoper rid himself of this conspicuous memento of his social bond with Lievens, negating its intended efficacy because, as he wrote in his diary, he did not want to "have any obligation" to the artist. ${ }^{42}$ Whether Huygens accepted Rembrandt's painting, refused, or disposed of it, his support after this period apparently dwindled. Reconstructing the circumstances of Rembrandt's presentation of this gift, however, confers on the Blinding - or whichever canvas was indeed sent-a remarkable ability to embody and affect the personal ties that flowed around and through it. As a result, the painting assumes a much more active role in describing the relationships between Rembrandt and his patrons.

\section{Rembrandt's Later Printed Gifts}

19 Gift giving in Rembrandt's later career differed from the courtly, hierarchical exchanges of the 1630s, while at the same time becoming more pronounced and more regular. In the late 1640s 
and 1650s in particular, he created a number of distinctive works for Amsterdam collectors and liefhebbers that appear to have been designed to function within a context of gift exchange. ${ }^{43}$ For the purposes of this study I will address only his later prints in connection with gift exchange, but the exceptional character of some of these works indicates the growing importance of gift giving in Rembrandt's practice and within circles of collectors. The distinctiveness of these prints also suggests that Rembrandt increasingly exploited the capacity of his art to exercise agency in forming and consolidating assemblies of art lovers.

20 A very old tradition, probably dating to the early eighteenth century, has it that Rembrandt's 100 Guilder Print (Christ Healing the Sick, fig. 3) was originally exchanged as a gift between Rembrandt and his intimates. ${ }^{44}$ On the verso of a first-state impression on Japanese paper in the Rijksmuseum is an old Dutch inscription referring to the print as being traded by "my special friend" Rembrandt for an impression of Marcantonio Raimondi's The Plague (La Pesta). ${ }^{45}$ Another French inscription, dating from the eighteenth century, elaborates by attributing the rarity of The 100 Guilder Print to Rembrandt's distribution of only a limited number of impressions among his friends, noting that not one was sold on the market in Rembrandt's time. ${ }^{46}$ Ironically the print's title, which refers to its exceptionally high market value of 100 guilders (a fact already acknowledged in Rembrandt's lifetime as extraordinary, if not excessive), diverts attention away from an important part of its original, apparently very different circumstances of exchange. ${ }^{47}$

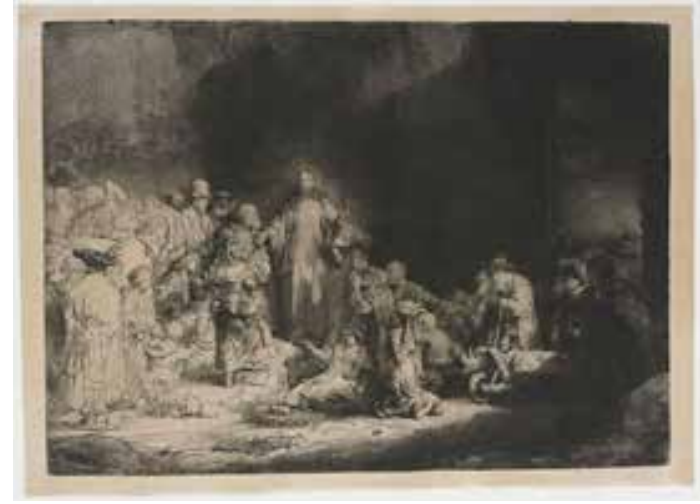

Fig. 3 Rembrandt van Rijn, The 100 Guilder Print (Christ Healing the Sick), ca. 1648, etching, first state, $280 \times 394$ mm. Rijksmuseum, Amsterdam, inv. no. RP-P-1962-1 (@ Photo Rijksmuseum) (artwork in the public domain)

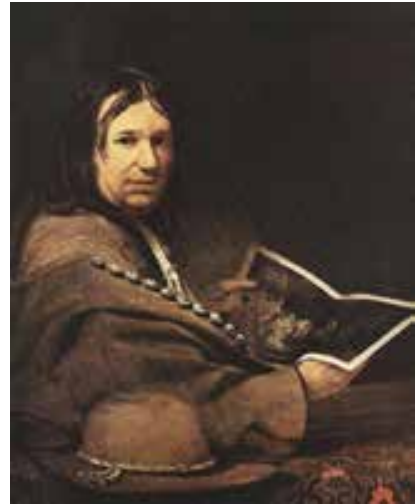

Fig. 4 Arent de Gelder, Portrait of a Man with Rembrandt's Hundred Guilder Print, oil on canvas, $79.5 \times 64.5 \mathrm{~cm}$. Hermitage, Saint Petersburg, inv. no. 790 (artwork in the public domain)

21 The linking of the print to exclusive conditions of production and reception also finds some support in Arent de Gelder's unusual painting Portrait of a Man with Rembrandt's Hundred Guilder Print (fig. 4), which represents what is most likely an unknown collector holding an impression of The 100 Guilder Print and turning to the viewer as if engaged in an intimate discussion of Rembrandt's artistry. ${ }^{48}$ The virtuoso 100 Guilder Print assumed and addressed a devoted audience of liefhebbers; they would have appreciated Rembrandt's unprecedented rendering of the various verses of chapter nineteen of Matthew's gospel as a unified narrative scene and a display of the range of his printmaking skills, from light sketch-like touches to elaborate detail and velvety chiaroscuro effects. ${ }^{49}$

Inscriptions by Rembrandt on a few prints also seem to confirm that individuated impressions 
were presented to an inner sanctum of collectors. On the back of a superb seventh-state impression of Christ Presented to the People on Japanese paper in the Lugt collection (fig. 5), for example, Rembrandt wrote in red chalk: "Kattenburgh," referring either to the Amsterdam art dealer Dirck van Kattenburgh or his brother Otto. ${ }^{50}$ And a second-state impression on Japanese paper of Woman at the Bath with a Hat Beside Her in Washington (fig. 6) is inscribed: "for the surgeon" (Voor 't Chirurg), indicating that perhaps this was intended for the surgeon Arnout Tholinx, whom Rembrandt had portrayed in both a portrait etching (fig. 7) and a small painting in about $1656 .{ }^{51}$
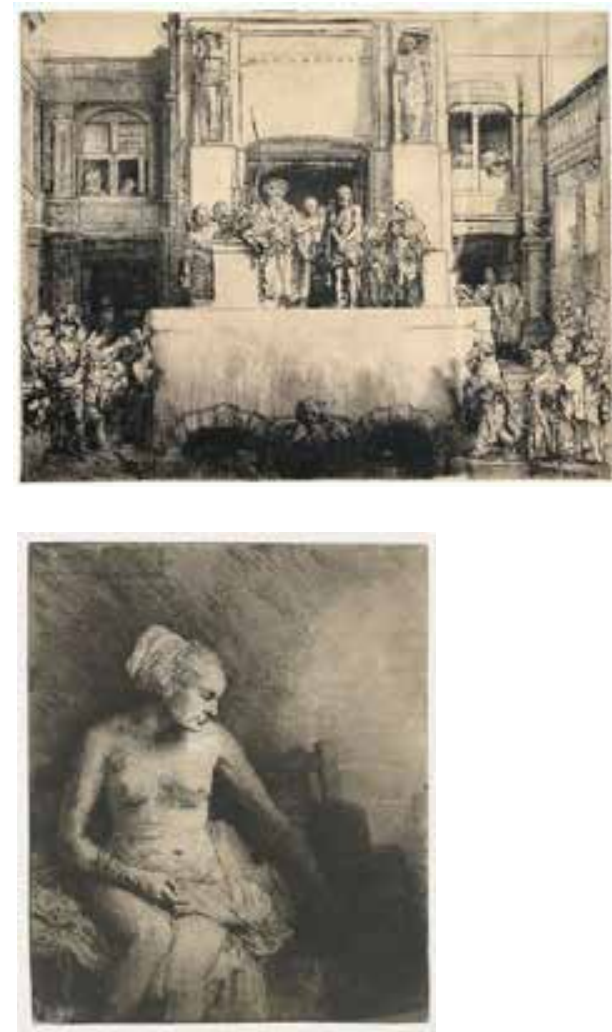

Fig. 6 Rembrandt van Rijn, Woman at the Bath with a Hat Beside Her, 1658, etching and drypoint, second state, $155 \mathrm{x}$ 128 mm. Rijksmuseum, Amsterdam, inv. no. RP-P-0B-261 (๔ Photo Rijksmuseum) (artwork in the public domain)
Fig. 5. Rembrandt van Rijn, Christ Presented to the People, 1655, drypoint, seventh state, 360 x $450 \mathrm{~mm}$. Rijksmuseum, Amsterdam, inv. no. RP-P-0B-611 (@ Photo Rijksmuseum) (artwork in the public domain)

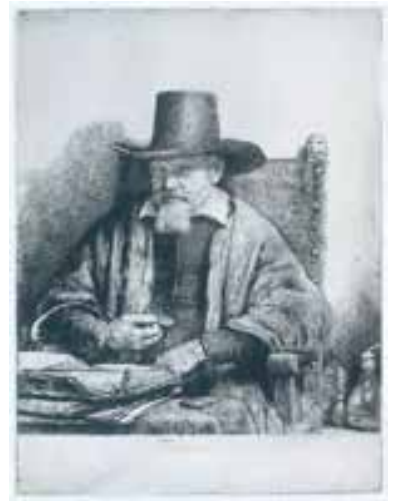

Fig. 7 Rembrandt van Rijn, Arnout Tholinx, ca. 1656, etching, drypoint, and burin, second state, $19.7 \times 14.8$ mm. Rijksmuseum, Amsterdam, inv. no. RP-P-0B-577 (๔ Photo Rijksmuseum) (artwork in the public domain)

23 Traces of Rembrandt's personalized exchanges of prints among men with whom he enjoyed close relations may also be found in titles that continue to be used for certain prints: Christ Preaching from about 1652 (fig. 8) is still known as La Petite Tombe (La Tombe's little plate), most likely in reference the art lover, dealer, and artist Pieter de La Tombe. ${ }^{52}$ De La Tombe, whom Rembrandt is recorded to have painted twice, both as a young man and at a more advanced age, was one of the artist's intimates and supporters in these years and is mentioned in several documents dating from the period $1650-58$.

24 The dissemination of these impressions in personalized, noncommercial circuits of exchange is a revealing feature of Rembrandt's art. Erik Hinterding's important research on watermarks has clarified that Rembrandt came to focus his production on two discrete groups of print collectors or markets: the highly discriminating customer and the more anonymous buyer. ${ }^{53}$ Deluxe impres 


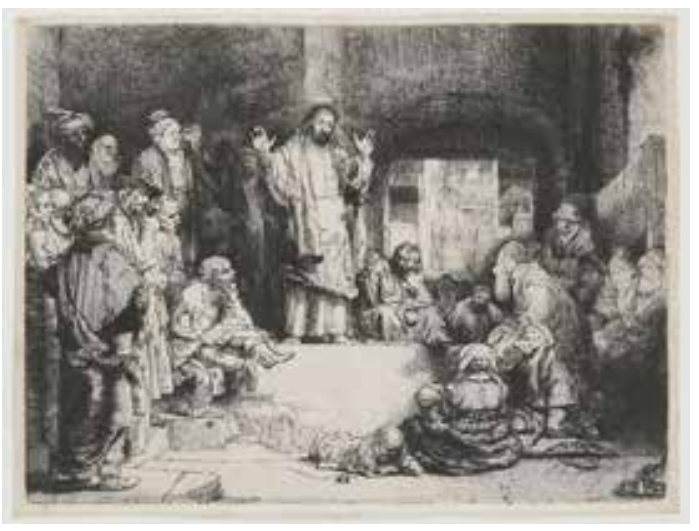

Fig. 8 Rembrandt van Rijn, Christ Preaching (La Petite Tombe), ca. 1652, etching and drypoint, only state, $154 \times 206 \mathrm{~mm}$. Rijksmuseum, Amsterdam, inv. no. RP-P-1962-35 (@ Photo Rijksmuseum) (artwork in the public domain)

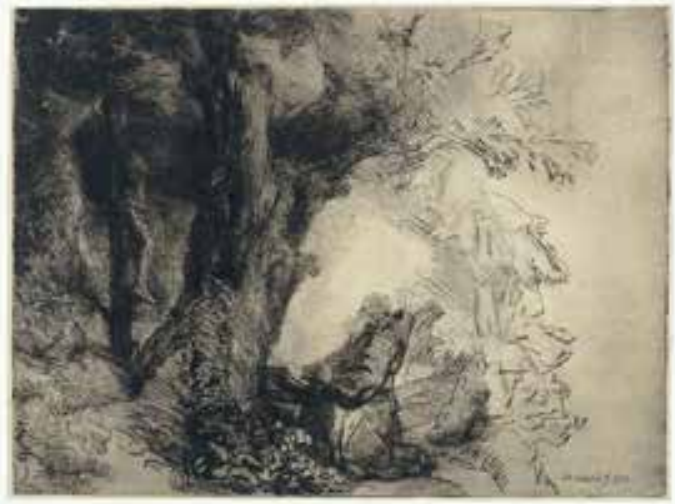

Fig. 9 Rembrandt van Rijn, Saint Francis Beneath a Tree Praying, 1657, drypoint and etching, first state, $180 \times 241 \mathrm{~mm}$. Rijksmuseum, Amsterdam, inv. no. RP-P-0B-171 (@ Photo Rijksmuseum) (artwork in the public domain)

sions of early states, such as these prints, with varied amounts of surface tone and often printed on Japanese paper or vellum, would have been available only to a small network of admirers. Once Rembrandt considered his plates finished, they were printed and reprinted as relatively uniform editions on standard European paper for a broader market. Thus, he cultivated a select and discerning audience for his early, experimental states. The many extra impressions of Rembrandt's trial-proof states that are preserved, such as the first incomplete state of Saint Francis Beneath a Tree Praying (fig. 9), which is printed on vellum and even signed and dated 1657, also indicate that he was encouraging these collectors to, as Thomas Rassieur puts it, "look over his shoulder," as witnesses to the creative process. ${ }^{54}$ The Woman at the Bath with Hat Beside Her from 1658 (fig. 6), where a partially undressed model sits unselfconsciously next to a man's hat, even seems to offer this discrete group of familiars privileged, confidential access to the private world of Rembrandt's studio. ${ }^{55}$ Embedding Rembrandt's works in a structure of intimate relations with collectors thus allows us to recognize self-conscious features designed to initiate a reciprocal exchange with attentive beholders. When received in the form of a gift, this intimacy of address must have been tremendously reinforced, endowing the print with a powerful agency in creating and sustaining the social ties that revolved around its presentation, reception, and display.

Evidently Rembrandt recognized that the flexibility and mobility of the print facilitated the spontaneous presentations required by the ethics of the gift. The medium's reproducibility and relatively modest price compared to painting made it ideally suited for gift giving, and Rembrandt's increasing focus on deluxe, individuated impressions and technically unusual prints undoubtedly enhanced the appeal of receiving one of his presentations. In embracing prints as a way to conduct personalized relations with an inner sanctum of liefhebbers, Rembrandt apparently sought to evade the alienation and taint of commercial transactions. Nicolas Poussin similarly preferred to present his works as exchanges of friendship, not money (though money certainly was exchanged in both cases). ${ }^{56}$ Rembrandt's withdrawal of himself and his art from merely utilitarian calculations and relations-his defiance of the economics of conventional artistic patronage-must have been particularly poignant in the increasingly market-oriented economy of early capitalist Holland. 
Dutch collectors also appreciated the capacity of Rembrandt's prints to affect personal attachments, as his portrait prints apparently also circulated as gifts to foster intimate, noncommercial relations. Rembrandt produced only about twenty portrait prints apart from self-portraits, and he was personally associated with most of the sitters. ${ }^{57}$ Some of them were members of Rembrandt's inner sanctum and most were not public figures of whom portrait prints were normally made and circulated. The informal imagery Rembrandt developed for these prints constituted and sustained the intimacy of his relations with the men, and some prints were clearly conceived to fulfill a private role in the relations among his familiars. Two celebrated and closely allied portraits are the etchings Jan Six from 1647 (fig. 10) and Abraham Francen (fig. 11) from about ten years later. Rembrandt's relationship with the wealthy dilettante Six at times went beyond that of a mere business arrangement, while Francen, an apothecary and art lover of modest means, was a close friend entrusted with the guardianship of Rembrandt's daughter Cornelia. ${ }^{58}$ These liefhebbers are depicted at a remove from the social and aesthetic conventions of public life, leisurely pursuing the literary and visual arts and thus enacting the appreciation for art that served as the basis for their intimacy with Rembrandt. The casual poses and self-contained gazes of Six and Francen also reinforce the portraits' intimate character. Leaning on a windowsill, Six is absorbed in a text that may be one of his own literary works, perhaps his tragedy Medea, for which Rembrandt would etch a frontispiece in 1648. Francen is ensconced in a cabinet as he admires a print or a drawing by an open window, mirroring and thematizing our experience as viewers of the print.

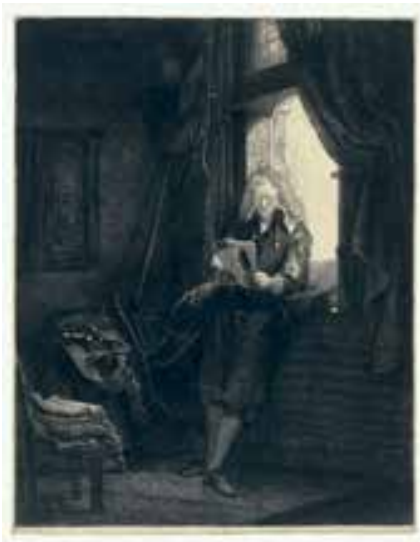

Fig. 10 Rembrandt van Rijn, Jan Six, 1647, etching, drypoint, and burin, $246 \times 191 \mathrm{~mm}$. Rijksmuseum, Amsterdam, inv. no. RP-P-0B-578 (@ Photo Rijksmuseum) (artwork in the public domain)

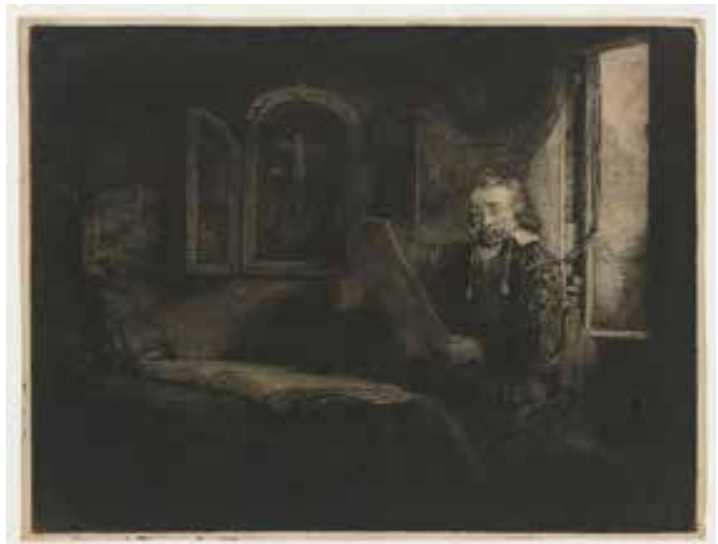

Fig. 11 Rembrandt van Rijn, Abraham Francen, ca. 1657, etching, drypoint, and burin, $159 \times 208$ mm. Rijksmuseum, Amsterdam, inv. no. RP-P-OB-531 (@ Photo Rijksmuseum) (artwork in the public domain)

27 Like most of Rembrandt's portrait prints, these lack the customary margins bearing captions identifying the sitters. (Only in the rare fourth state of Jan Six was a roughly scratched identifying inscription [IAN SIX AE: 29] squeezed into the very narrow border.) This was exceptional in the portrait print trade, where inscriptions were needed to broadcast a sitter's status given the print's wide circulation. ${ }^{59}$ In contrast, Six's and Francen's portraits, often printed on Japanese paper and sometimes on vellum, would have been intended for distribution within inner circles rather than as official images. Works of private, exclusive address, they were likely presented as gifts, and Rembrandt designed them to heighten the impression of familiarity. The recipient or beholder is welcomed into the private spaces of these collectors as an unacknowledged yet privileged guest, becoming a member of the sitter's network of like-minded art lovers. Rembrandt, whose artistry 
serves as the admired object being exchanged, is also implied as a participant in this informal and familiar encounter.

28 When offered by Six or Francen as a token of personal bonds these distinctive and exquisite prints would have unleashed a strong social agency that epitomizes the task Actor-Network-Theory attributes to objects in constituting and ordering social activity. Conceived by Rembrandt both to acknowledge and activate intimate reciprocities between subject and beholder, the portraits were empowered by the conditions of their trade to materialize and extend the reciprocal ties through which these networks were negotiated. The dramatic contrast in the social positions of Six and Francen, moreover, not only exemplifies the shift in Rembrandt's patronage base away from the patrician elite and toward art lovers of the well-to-do burgher class but also suggests that the appreciation for and circulation of his prints fostered the possibility of asymmetrical social alliances. ${ }^{60}$

29 Rembrandt's innovative portrait prints had become markers of discernment among Amsterdam's liefhebbers, and entry into the network of sitters for whom he created them was both highly desirable and not easily attained. In 1655 the collector Otto van Kattenburgh, brother of the dealer Dirck mentioned above, contracted with Rembrandt for a portrait print to be done "from life, equal in quality to the portrait of Mr. Jan Six," for which he agreed to pay the staggering price of 400 guilders. ${ }^{61}$ Van Kattenburgh was clearly willing to pay exceptionally well to have himself portrayed in a medium Rembrandt normally reserved for intimates and close associates. ${ }^{62}$ No portrait is known of Van Kattenburgh, and his proposed arrangement with Rembrandt seems to have come to nothing. But it has been suggested that the portrait of Francen, which is formally and technically similar to Six's etched portrait, Van Kattenburgh's specified model, may have originated in the aborted commission. ${ }^{63}$

30 Whatever the case may have been, the invocation of Six's portrait in both the Van Kattenburgh contract and Francen's portrait indicates that Rembrandt and members of his inner circle of admirers perceived these prints as visualizations of an aestheticized social ideal that might even transcend traditional social hierarchies. Rembrandt's printed portraits in effect materialized networks of association between art lovers of divergent social backgrounds, reinforcing and extending this aspiration through distribution among intimates, and beyond to collectors of various social levels. Printmaking's suitability as a medium of exchange thus enhanced these portraits' coconstructive agency in social interactions, and no doubt facilitated their ability to continue to exert influence beyond the immediate circumstances of the initial gift offering. Prints such as these must have contributed to the expansion and durability of networks of liefhebbers, even if Rembrandt did not achieve complete success in sustaining the ties that bound him and his art to these exclusive circuits during his lifetime. Rembrandt's singular portraits not only contain the trace of these social formations but also continue to exercise their agency, drawing the beholder into an intimate reciprocity with the sitters, the print, and Rembrandt himself.

\section{Acknowledgements}

Research for this study was generously supported by a Jeffrey Henderson Senior Fellowship from the Boston University Humanities Foundation and a National Endowment for the Humanities Senior Fellowship. I am grateful to my colleague Gregory Williams for introducing me to Ac- 
tor-Network-Theory, to Marina Bers for discussing ANT's scientific applications, and for the invaluable comments and suggestions made by two anonymous readers for the Journal of Historians of Netherlandish Art and Alison M. Kettering. I would also like to thank Marten Jan Bok and Harm Nijboer, in whose HNA Conference session "Social Network Analysis of Art Markets and Art Worlds” I delivered a version of this paper in May 2010.

Michael Zell is Associate Professor of Art History at Boston University. He is the author of Reframing Rembrandt: Jews and the Christian Image in Seventeenth-Century Amsterdam, has published numerous articles and essays, and is currently working on a book titled Rembrandt, Vermeer, and the Gift in Seventeenth-Century Dutch Art.

\section{List of Illustrations}

Fig. 1 Rembrandt van Rijn, The Blinding of Samson, 1636, oil on canvas, 206 x $276 \mathrm{~cm}$. Städelsches Kunstinstitut, Frankfurt, inv. no. 1383 (artwork in the public domain)

Fig. 2. Rembrandt van Rijn, The Return of the Prodigal Son, 1636, etching, 155 x $137 \mathrm{~mm}$. Rijksmuseum, Amsterdam, inv. no. RP-P-1961-1039 (@ Photo Rijksmuseum) (artwork in the public domain)

Fig. 3 Rembrandt van Rijn, The 100 Guilder Print (Christ Healing the Sick), ca. 1648, etching, first state, 280 x 394 mm. Rijksmuseum, Amsterdam, inv. no. RP-P-1962-1 (C Photo Rijksmuseum) (artwork in the public domain)

Fig. 4 Arent de Gelder, Portrait of a Man with Rembrandt's Hundred Guilder Print, oil on canvas, 79.5 x $64.5 \mathrm{~cm}$. Hermitage, Saint Petersburg, inv. no. 790 (artwork in the public domain)

Fig. 5. Rembrandt van Rijn, Christ Presented to the People, 1655, drypoint, seventh state, $360 \times 450$ mm. Rijksmuseum, Amsterdam, inv. no. RP-P-OB-611 (c) Photo Rijksmuseum) (artwork in the public domain)

Fig. 6 Rembrandt van Rijn, Woman at the Bath with a Hat Beside Her, 1658, etching and drypoint, second state, 155 x 128 mm. Rijksmuseum, Amsterdam, inv. no. RP-P-OB-261 (C Photo Rijksmuseum) (artwork in the public domain)

Fig. 7 Rembrandt van Rijn, Arnout Tholinx, ca. 1656, etching, drypoint, and burin, second state, 197 x 148 mm. Rijksmuseum, Amsterdam, inv. no. RP-P-OB-577 (@ Photo Rijksmuseum) (artwork in the public domain)

Fig. 8 Rembrandt van Rijn, Christ Preaching (La Petite Tombe), ca. 1652, etching and drypoint, only state, 154 x 206 mm. Rijksmuseum, Amsterdam, inv. no. RP-P-1962-35 (@ Photo Rijksmuseum) (artwork in the public domain)

Fig. 9 Rembrandt van Rijn, Saint Francis Beneath a Tree Praying, 1657, drypoint and etching, first 
state, 180 x 241 mm. Rijksmuseum, Amsterdam, inv. no. RP-P-OB-171 ( Photo Rijksmuseum) (artwork in the public domain)

Fig. 10 Rembrandt van Rijn, Jan Six, 1647, etching, drypoint, and burin, 246 x 191 mm. Rijksmuseum, Amsterdam, inv. no. RP-P-OB-578 (C Photo Rijksmuseum) (artwork in the public domain)

Fig. 11 Rembrandt van Rijn, Abraham Francen, ca. 1657, etching, drypoint, and burin, 159 x 208 mm. Rijksmuseum, Amsterdam, inv. no. RP-P-OB-531 (ㅇ Photo Rijksmuseum) (artwork in the public domain)

\footnotetext{
${ }^{1}$ Bruno Latour, Reassembling the Social: An Introduction to Actor-Network-Theory (Oxford and New York: Oxford University Press, 2007), 198.

${ }^{2}$ Bruno Latour, “The Berlin Key or How to Do Words with Things," trans. Lydia Davis, in Matter, Materiality, and Modern Culture, ed. P. M. Graves-Brown (London and New York: Routledge, 2000), 10. Cited in Bill Brown, “Thing Theory," Critical Inquiry 28 (2001): 12.

${ }^{3}$ Latour, Reassembling the Social, 82 .

${ }^{4}$ Ibid., 74.

${ }^{5}$ Ibid., 70.

${ }^{6}$ Ibid., 110-11.

${ }^{7}$ Ibid., 213-18.

${ }^{8}$ Pierre Bourdieu, Distinction: A Social Critique of the Judgment of Taste, trans. Richard Nice (Cambridge, Mass.: Harvard University Press, 1984).

${ }^{9}$ Latour, Reassembling the Social, 236.

${ }^{10}$ Ibid.

${ }^{11}$ See Antoine Hennion, "Pragmatics of Taste," in The Blackwell Companion to the Sociology of Culture, ed. Mark D. Jacobs and Nancy Weiss Hanrahan (Malden, Mass.: Blackwell, 2005), 131-44. Hennion (133-34) calls the history of art "a choice ally" and identifies three art-historical texts as important to his project: Michael Baxandall, Painting and Experience in Fifteenth-Century Italy (Oxford: Clarendon Press, 1972); Francis Haskell, Rediscoveries in Art (Ithaca, N.Y.: Cornell University Press, 1976); and Francis Haskell and Nicholas Penny, Taste and the Antique: The Lure of Classical Sculpture,1500-1900 (New Haven, Conn.: Yale University Press, 1981). Latour repeatedly cites Hennion's work (Latour, Reassembling the Social, 11, nn. 33, 217, and 237).

${ }^{12}$ Alfred Gell, Art and Agency: An Anthropological Theory (Oxford and New York: Clarendon Press, 1998). For a consideration of the applicability Gell's work to case studies from the history of art, see Robin Osborne and Jeremy Tanner, eds., Art's Agency and Art History (Oxford: Blackwell, 2007).

${ }^{13}$ Latour, Reassembling the Social, 148. See Rem Koolhaas and Bruce Mau, Small, Medium, Large, Extra-Large: Office for Metropolitan Architecture, ed. Jennifer Sigler (New York: Monacelli Press, 1995).

${ }^{14}$ See Gary Schwartz, Rembrandt: His Life, His Paintings (New York: Viking, 1985) and Svetlana Alpers, Rembrandt's Enterprise: The Studio and the Market (Chicago: University of Chicago Press, 1988).
} 
${ }^{15}$ See, in particular, S. A. C. Dudok van Heel, "Rembrandt van Rijn (1606-1669): A Changing Portrait of the Artist," in Rembrandt: The Master and His Workshop. Paintings, exh. cat., ed. Christopher Brown, Jan Kelch, and Pieter van Thiel (Gemäldegalerie SMPK at the Altes Museum, Berlin; Rijksmuseum, Amsterdam; and the National Gallery, London, 1991), 50-67; Paul Crenshaw, Rembrandt's Bankruptcy: The Artist, His Patrons, and the Art Market in Seventeenth-Century Netherlands (Cambridge: Cambridge University Press, 2006); Erik Hinterding, Rembrandt as an Etcher: The Practice of Production and Distribution, Studies in Prints and Printmaking 6, trans. Michael Hoyle (Ouderkerk aan den Ijssel: Sound and Vision, 2006); Mariët Westermann, Rembrandt (London: Phaidon, 2000); and Michael Zell, "The Gift Between Friends: Rembrandt's Art in the Network of His Patronal and Social Relations," in Rethinking Rembrandt, ed. Alan Chong and Michael Zell (Zwolle: Waanders, 2002), 173-93.

${ }^{16}$ For helpful discussions of Rembrandt's relationships with a network of merchant connoisseurs and art dealers in the 1650s and 1660s, see Roelof van Gelder and Jaap van der Veen, "A Collector's Cabinet in the Breestraat: Rembrandt as a Lover of Art and Curiosities," in Rembrandt's Treasures, exh. cat., Bob van den Boogert, et al. (Rembrandthuis, Amsterdam, 1999), 64-67; and Jaap van der Veen, "The Network of Collectors Around Rembrandt," in Rembrandt's Treasures, $141-45$.

${ }^{17}$ On Rembrandt and gift giving, see Zell, "The Gift Between Friends.” ${ }^{18}$ The classic study of gift exchange is Marcel Mauss, The Gift: The Form and Reason for Exchange in Archaic Societies, trans. W. D. Halls, foreword by Mary Douglas (New York and London: Routledge, 2002) (first published as Essai sur le don: Forme et raison de l'échange dans les sociétés archaïques, Lanné sociologique, n.s. 1 [Paris, 1925]). Subsequent anthropological literature on the gift is vast. Among the most influential and recent studies are: Claude Lévi-Strauss, The Elementary Structures of Kinship, trans. James Harle Bell and John Richard von Sturmer; ed. Rodney Needham (Boston: Beacon Press, 1969); Pierre Bourdieu, Outline of a Theory of Practice, trans. Richard Nice (Cambridge: Cambridge University Press,1977); Pierre Bourdieu, The Logic of Practice, trans. Richard Nice (Stanford, Calif.: Stanford University Press, 1990); Pierre Bourdieu, Practical Reason: On the Theory of Action, trans. Randall Johnson (Stanford, Calif.: Stanford University Press,1998); Marshall Sahlins, Stone Age Economics (Chicago: Aldine-Atherton, 1972); Arjun Appadurai, ed., The Social Life of Things: Commodities in CulturalPerspective (Cambridge and New York: Cambridge University Press, 1986); Marilyn Strathern, The Gender of the Gift: Problems with Women and Problems with Society in Melanesia (Berkeley, Calif.: University of California Press, 1988); Annette Weiner, Inalienable Possessions: The Paradox of Keeping-While-Giving (Berkeley, Calif.: University of California Press, 1992);James Carrier, Gifts and Commodities: Exchange and Western Capitalism Since 1700 (London and New York: Routledge, 1995); Alan Schrift, ed., The Logic of the Gift: Toward an Ethic of Generosity (New York: Routledge, 1997); Maurice Godelier, The Enigma of the Gift, trans. Nora Scott (Chicago: University of Chicago Press, 1999); and Mark Osteen, The Question of the Gift: Essays Across Disciplines (London and New York: Routledge, 2002).

${ }^{19}$ See Natalie Zemon Davis, "Beyond the Market: Books as Gifts in Sixteenth-Century France," Royal Historical Society Transactions 33 (1983): 69-88; Natalie Zemon Davis, The Gift in Sixteenth-Century Franc (Madison, Wis., University of Wisconsin Press, 2000); Mario Biagioli, Galileo, Courtier: The Practice of Science in the Culture of Absolutism (Chicago: University of Chicago Press, 1983); Sharon Kettering, "Gift-Giving and Patronage in Early Modern France," French History 2 (1988): 419-47; Sharon Kettering, Patrons, Brokers, and Clients in 
Seventeenth-Century France (New York: Oxford University Press, 1986); Lisa Jardine, Worldly Goods: A New History of the Renaissance (New York and London: W. W. Norton, 1998); Antoon Vandevelde, Gifts and Interests (Louvain: Peeters, 2000); and Gadi Algazi, Valentin Groebner, and Bernhard Juseen, eds., Negotiating the Gift: Pre-Modern Figurations of Exchange (Philadelphia: Vandenhoeck and Ruprecht, 2003).

${ }^{20}$ Irma Thoen, Strategic Affection? Gift Exchange in Seventeenth-Century Holland (Amsterdam: Amsterdam University Press, 2007).

${ }^{21}$ Geert Janssen, Princely Power in the Dutch Republic, trans. J. C. Grayson (Manchester, England, and New York: Manchester University Press, 2008), esp. 175-79.

${ }^{22}$ For early modern art and gift giving, see, in particular, Genevieve Warwick, "Gift Exchange and Art Collecting: Padre Sebastiano Resta's Drawing Albums," Art Bulletin 79 (1997): 630-46; Alexander Nagel, "Gifts for Michelangelo and Vittoria Colonna," Art Bulletin 79 (1997): 647-68; Alexander Nagel, "Art as Gift: Liberal Art and Religious Reform in the Renaissance," in Negotiating the Gift, 319-60; Richard Spear, The 'Divine Guido': Religion, Sex, Money and Art in the World of Guido Reni (New Haven: Yale University Press, 1997), esp. 211-15; and Michiel Roscam Abbing, "Samuel van Hoogstraten's Personal Letter-Rack Paintings: Venerations with a Message," in The Universal Art of Samuel van Hoogstraten (1627-1678), Painter, Writer, and Courtier, ed. Thijs Weststeijn (forthcoming). For an in-depth study of the importance of gift giving to the life and work of a celebrated scholar painter of early modern China, see Craig Clunas, Elegant Debts: The Social World of Wen Zhengming, 1470-1559 (Honolulu: University of Hawaii Press, 2004). ${ }^{23}$ On Seghers, see, in particular, Walter Couvreur, "Danïel Seghers' inventaris van door hem geschilderde stukken," Gentse bijdragen tot de kunstgeschiedenis en de oudheidkunde 20 (1967): 87-158; and Peter van der Ploeg, Carola Vermeeren, et al., Princely Patrons: The Collection of Frederik Hendrik of Orange and Amalia von Solms in The Hague, exh. cat. (Mauritshuis, The Hague, 1997), 246-49.

${ }^{24}$ On Reni and gift exchange, see Spear, The 'Divine Guido,' 211-15.

${ }^{25}$ Quoted in Spear, The 'Divine Guido,' p. 212. See Carlo Cesare Malvasia, The Life of Guido Reni, trans. and with an introduction by Catherine Enggass and Robert Enggass (University Park, Pa., and London: Pennsylvania State University Press, 1980), 114.

${ }^{26}$ Eric Jan Sluijter, "Determining Value on the Art Market in the Golden Age: An Introduction," in Art Market and Connoisseurship: A Closer Look at Paintings by Rembrandt, Rubens, and Their Contemporaries, ed. Anna Tummers and Koenraad Jonckheere (Amsterdam: Amsterdam University Press, 2008), esp. 13-16. On Rembrandt's disputes with clients, see, in particular, Crenshaw, Rembrandt's Bankruptcy, chapter 6, 110-35.

${ }^{27}$ Quoted and translated in Sluijter, "Determining Value," 15. For the documents, see Lauro Magnani, "1666: Een onbekende opdracht uit Genua voor Rembrandt," Kroniek van het Rembrandthuis (2007): 2-17.

${ }^{28}$ See, in particular, Crenshaw, Rembrandt's Bankruptcy.

${ }^{29}$ For the letter, see Walter Strauss and Marjon van der Meulen, with the assistance of S. A. C. Dudok van Heel and P. J. M. de Baar, The Rembrandt Documents (New York: Abaris Books, 1979), doc. $1639 / 2$.

${ }^{30}$ See Josua Bruyn, et al., A Corpus of Rembrandt Paintings, vol. 3 (The Hague, 1989), 192-94, no. A119. Schwartz, Rembrandt, 130-31 and 178, proposes Danäe, initially dated 1636 and reworked in the early 1640s, as the painting Rembrandt sent to Huygens, and which Schwartz believes was returned to the artist. The authors of $A$ Corpus reject this suggestion, though it is reiterated in 
Gary Schwartz, Rembrandt's Universe: His Art, His Life; His World (London: Thames and Hudson, 2006), 343.

${ }^{31}$ For Huygens's position as secretary and his role in expanding the stadtholder's art collection, see, in particular, Peter van der Ploeg and Carola Vermeeren, "From the 'Sea Prince's' Monies: The Stadhouder's Art Collection," in Van der Ploeg and Vermeeren, Princely Patrons, 59-60. For Huygens as an art connoisseur and collector, see Inge Broekman, De rol van de schilderkunst in het leven van Constantijn Huygens, 1596-1687 (Hilversum: Verloren, 2005).

${ }^{32}$ On the Passion cycle and Rembrandt's seven surviving letters to Huygens discussing payments and deliveries of the paintings, see Horst Gerson, Seven Letters by Rembrandt, trans. Yda D. Ovink (The Hague: L. J. C. Boucher, 1961).

${ }^{33}$ Rembrandt to Huygens, January 27, 1639. See Strauss and van der Meulen, Rembrandt Documents, doc. 1639/4.

${ }^{34}$ Rembrandt to Huygens, February 1636. See Strauss and van der Meulen, Rembrandt Documents, doc. $1636 / 1$.

${ }^{35}$ Rembrandt to Huygens, 1639. See Strauss and van der Meulen, Rembrandt Documents, doc. $1639 / 6$.

${ }^{36}$ See, in particular, Schwartz, Rembrandt, 116-17.

${ }^{37}$ On the taboo of explicitness, see Pierre Bourdieu, Practical Reason: On the Theory of Action, trans. Randall Johnson (Stanford, Calif.: Stanford University Press, 1998), 96 ("The economy of symbolic goods").

${ }^{38} \mathrm{My}$ characterization of the patron-client relationship in the stadtholder's court relies on the analysis of Medici court culture in Biagioli, Galileo, Courtier, esp. 36-41, and on studies of the French court in Kettering, "Gift-Giving and Patronage," and Kettering, Patrons, Brokers, and Clients.

${ }^{39}$ See Biagioli, Galileo, Courtier, esp. 48.

${ }^{40}$ Broekman, Rol van het schilderkunst, 41-42, believes that Huygens likely refused the painting. As she noted, The Blinding of Samson is not recorded in the 1785 inventory of the estate of Huygens's great-great granddaughter Susanna Louise Huygens, nor did Huygens mention the picture in any of his writings.

${ }^{41}$ As suggested in Bruyn, et al.,A Corpus, 3:193.

${ }^{42}$ Jaap van der Veen, “Patronage for Lievens' Portraits and History Pieces, 1644-1674," in Jan Lievens: A Dutch Master Reconsidered, exh. cat., Arthur K. Wheelock Jr., et al. (National Gallery of Art, Washington, D.C.; Milwaukee Art Museum; and Rembrandthuis, Amsterdam, 2008), 31. The quotation is from a letter Huydecoper wrote to "de heer Sandra" on September 16, 1660 (Huydecoper Family Archive, inv. no. 56). Huydecoper apparently sold the picture to the art dealer Gerrit Uylenburgh, in whose stock it was recorded in 1675. See Friso Lammertse and Jaap van der Veen, Uylenburgh and Son: Art and Commerce from Rembrandt to De Lairesse, 1625-1675, exh. cat. (Dulwich Picture Gallery, London; and Rembrandthuis, Amsterdam, 2006), 298, n. 115. ${ }^{43}$ For other details on Rembrandt' s gift giving in his later career, see Zell, "Gift Among Friends," 183-93.

${ }^{44}$ Barbara Welzel first drew attention to this tradition. See Holm Bevers, Peter Schatborn, and Barbara Welzel, Rembrandt: The Master and His Workshop; Drawings \& Prints, exh. cat. (Altes Museum, Berlin; Rijksmuseum, Amsterdam; and National Gallery, London, 1991), 244-45, cat. 27.

${ }^{45}$ The inscription on the reverse of an impression in the Rijksmuseum, Amsterdam, reads: 
"Vereering van mijn speciaele / vriend Rembrand, tegens de / Pest van M. Antony" (Traded from my special friend Rembrandt for the Plague by Marcantonio). See Cornelis Hostede de Groot, Die Urkunden über Rembrandt, 1575-1721 (The Hague: M. Nijhoff, 1906), no. 266, where it is attributed to the art dealer and collector Jan Pietersz. Zomer. S. A. C. Dudok van Heel, "Jan Pietersz. Zomer (1641-1724): Makelaar in schilderijen (1690-1724)," Jaarboek Amstelodamum 69 (1977): 98, rejects the identification.

${ }^{46}$ The inscription is transcribed in Erik Hinterding, Ger Luijten, and Martin Royalton-Kisch, Rembrandt the Printmaker, exh. cat. (British Museum, London, and Rijksmuseum, Amsterdam, 2000), 253, cat. 61: "Rembrand amoureux d'une / Estampe de M.A. savoir la / Peste, que son ami J. Pz. Zoomer, avoir de fort belle / Impression, \& ne pouvant / l'Engager à lui vendre, / Lui fit present, pour l'avoir / de Cette Estampe-ci, plus- / rares \& plus Curieux Encore / que l'Estampe l'on Nome [?] / de Hondert Guldens Print, par / les Addition dans Clair obscur / qu'il y a dans Celle-ci, / don't il n'y a eu, suivant le raport / qui m'en Ete fait, que tres peu d'Impressions, don't / Aucune n'a jamais été vendûe / dutemps de Rembrand, mais / distribuées entre ses amis" (Rembrandt, in love with a print by Marcantonio known as the Plague, of which his friend J. $\mathrm{Pz}$ Zomer had a very beautiful impression, and could not be convinced to sell it to him, made a present to have it of this print, rarer and more curious than the print one calls [?] the Hundred Guilder Print, by the additions in the chiaroscuro that are in this one, of which, according to a report made to me, there were not but very few impressions made, of which not one was ever sold in Rembrandt's time, but distributed among his friends.) ${ }^{47}$ The print's title appears to have originated in the seventeenth century. Martin Royalton-Kisch in Hinterding, Luijten, and Royalton-Kisch, Rembrandt the Printmaker, 255, cat. 61, and Hinterding, Rembrandt as an Etcher, 60-61, quote a letter written in 1654 by Jan Meyssens of Antwerp to Charles Vanden Bosch, bishop of Bruges: "Also available here [in Antwerp] is the most remarkable print by Rembrandt, in which Christ is healing the sick, and I know that it has been sold various times in Holland for 100 guilders and more; and it is as large as this sheet of paper [on which the letter is written], very fine and lovely, but ought to cost 30 guilders. It is very beautiful and pure." For the letter, see Emile van den Bussche, "Un évéque bibliophile: Notes sur la bibliothèque et le cabinet de gravures de Charles Vanden Bosch, neuvième évèque de Bruges; ses relations avec Elzévirs, Meyssens, etc.," La Flandre: Revue des monuments d'histoire et d'antiquites 13 (1880): 358-59.

${ }^{48}$ Noted by Welzel in Bevers, Schatborn, and Welzel, Rembrandt: The Master and His Workshop, 245, cat. 27. On De Gelder's painting, see Arent de Gelder (1645-1727): Rembrandts laatste leerling, exh. cat. (Dordrechts Museum, and Wallraf-Richartz-Museum, Cologne, 1999), 220-23, cat. 42 .

${ }^{49}$ On The Hundred Guilder Print, see, in particular, Hinterding, Luijten, and Royalton-Kisch, Rembrandt the Printmaker, 253-58, cat. 61.

${ }^{50}$ Ibid., 322, cat. 78. Crenshaw, Rembrandt's Bankruptcy, 175, n. 102, suggests that Rembrandt may have presented the print as a gift to Dirck van Kattenburgh in thanks for facilitating a financial arrangement with his brother Otto in 1655.

${ }^{51}$ For the inscription, see Christopher White and Karel G. Boon, Rembrandt's Etchings: An Illustrated Critical Catalogue (Amsterdam: M. Hertzberger, 1969), 1:97, where it is suggested, implausibly, that Rembrandt presented the print to the surgeons' guild in gratitude for allowing him access to their facilities to draw from the nude. See also Julia Lloyd Williams, et al., Rembrandt's Women, exh. cat. (National Gallery of Scotland, Edinburgh, and National Gallery, London, 2001), 
224, cat. 128. On Rembrandt and Tholinx, see, in particular, Rembrandt the Printmaker, 329-32, cat. 82; Stephanie Dickey, Rembrandt: Portraits in Print (Amsterdam and Philadelphia: John Benjamins, 2004), 141-42; and Crenshaw, Rembrandt's Bankruptcy, 60. For Tholinx's life, see D. van Tol, "Een portret van dr. Arnout Tholinx (1607-1679)," Jaarboek van het Centraal Bureau voor Genealogie en het Ikonografisch Bureau 37 (1983): 139-50. Rembrandt's painted portrait of Tholinx is in the Musée Jacquemart-André, Paris.

${ }^{52}$ Van Gelder and Van der Veen, "A Collector's Cabinet in the Breestraat," 65 and Isabella van Eeghen, "De familie de La Tombe en Rembrandt," Oud Holland 71 (1956): 43-49. The plate may also have been commissioned by Pieter's relative Nicolaes de La Tombe, as is suggested in Hinterding, Luijten, and Royalton-Kisch, Rembrandt the Printmaker, 281, cat. 68.

${ }^{53}$ Hinterding, Rembrandt as an Etcher, esp. 118-24 and 144-45, and Hinterding, "Watermark Research as a Tool for the Study of Rembrandt's Etchings," in Hinterding, Luijten, and Royalton-Kisch, Rembrandt the Printmaker, 23-35. For additional remarks on Rembrandt's later printmaking and exclusive circles of collectors, see Ger Luijten, "Rembrandt the Printmaker: The Shaping of an Oeuvre," in Hinterding, Luijten, and Royalton-Kisch, Rembrandt the Printmaker, esp. 17-22.

${ }^{54}$ Thomas Rassieur, "Looking Over Rembrandt's Shoulder: The Printmaker at Work," in Clifford Ackley, et al., Rembrandt's Journey: Painter, Draftsman, Etcher, exh. cat. (Museum of Fine Arts, Boston, and Art Institute of Chicago, 2003), esp. 57-58; Luijten, "Shaping of an Oeuvre," 21; and Hinterding, Luijten, and Royalton-Kisch, Rembrandt the Printmaker, esp. 342-43, cat. 85. ${ }^{55}$ As Elizabeth Honig observes, Rembrandt "allows us an inappropriate view of the woman in a state of pre-aestheticized privacy." See Elizabeth Alice Honig, "The Space of Gender in Seventeenth-Century Dutch Painting," in Looking at Seventeenth-Century Dutch Painting: Realism Reconsidered, ed. Wayne Franits (Cambridge, England: Cambridge University Press, 1997), 192.

${ }^{56}$ For Poussin's cultivation of his patrons as friends, see Elizabeth Cropper and Charles Dempsey, Nicolas Poussin: Friendship and the Love of Painting (Princeton, N.J.: Princeton University Press, 1996), 177-215.

${ }^{57}$ On Rembrandt's portrait prints, see, in particular, Dickey, Portraits in Print, and Rudolf E. O. Ekkart and E. Ornstein-van Slooten, Oog in oog met de modellen van Rembrandts portret-etsen (Face to Face with the Sitters of Rembrandt's Etched Portraits), exh. cat. (Rembrandthuis, Amsterdam, 1986).

${ }^{58}$ For Rembrandt's etched portraits of Six and Francen and his intimate relations with these collectors from very different social strata, see, in particular, Dickey, Portraits in Print, 112-19 and $142-49$.

${ }^{59}$ Ekkart, introduction in Oog in Oog, esp. 13-14.

${ }^{60}$ Dickey, Portraits in Print, 148, notes that Francen did not have the means to own the impressive curiosity cabinet in which Rembrandt depicted him.

${ }^{61}$ The wording of the 1655 contract reads: "een conterfeijtsel van Otto van Kattenburch, twelck de voorsz. van Rijn sal naer't leven etsen, van deucht als het conterfeijtsel van d'Heer Jan Six" (A portrait of Otto van Kattenburgh which the aforementioned van Rijn shall etch from life, equal in quality to his portrait of Mr. Jan Six) (see Strauss and Van der Meulen, Rembrandt Documents, doc. 1655/8). For commentary on the negotiations, see, in particular, Crenshaw, Rembrandt's Bankruptcy, 64-65. At the time of his financial crisis, Rembrandt entered into the contract as part of his negotiation to purchase a new, less expensive house owned by Van Kattenburgh on the Handboogstraat. Rembrandt agreed to etch Van Kattenburgh's portrait and supply other 
works by his own hand and from his collection as part of the payment. It is not clear why the arrangement fell through.

${ }^{62}$ Crenshaw, Rembrandt's Bankruptcy, 64-65. Hinterding, Rembrandt as an Etcher, 64, concludes that the steep price likely "gives a faithful picture of the prices Rembrandt could charge for commissions of this kind in 1655."

${ }^{63}$ Hinterding, Rembrandt as an Etcher, 66. The idea that the Francen print was a reworking of the aborted portrait of Van Kattenbergh was first advanced by Jan Six (a descendant of Rembrandt's patron) in "Iets over Rembrandt," Oud Holland 11 (1893): 156, and "Rembrandt's voorbreiding van de etsen van Jan Six en Abraham Francen," Onze Kunst 14 (1908): 53-65, and revived by Crenshaw, Rembrandt's Bankruptcy, 65-66, and 174-75, n. 102. Dickey, Portraits in Print, 148, suggests that the Francen portrait may depict Abraham Francen's brother Daniel, a successful surgeon who loaned Rembrandt 3,150 guilders in 1656. No portrait of Daniel Francen is known, however.

\section{Bibliography}

Abbing, Michiel Roscam. "Samuel van Hoogstraten's Personal Letter-Rack Paintings: Venerations with a Message." In The Universal Art of Samuel van Hoogstraten (1627-1678), Painter, Writer, and Courtier. Edited by Thijs Weststeijn. Forthcoming.

Algazi, Gadi, Valentin Groebner, and Bernhard Juseen, eds. Negotiating the Gift: Pre-Modern Figurations of Exchange. Philadelphia: Vandenhoeck and Ruprecht, 2003.

Alpers, Svetlana. Rembrandt's Enterprise: The Studio and the Market. Chicago: University of Chicago Press, 1988.

Appadurai, Arjun, ed. The Social Life of Things: Commodities in Cultural Perspective. Cambridge and New York: Cambridge University Press, 1986.

Arent de Gelder (1645-1727): Rembrandts laatste leerling. Exh. cat. Dordrecht: Dordrechts Museum; and Cologne: Wallraf-Richartz-Museum, 1999.

Bevers, Holm, Peter Schatborn, and Barbara.Welzel. Rembrandt: The Master and His Workshop; Drawings \& Prints. Exh. cat. Berlin: Altes Museum; Amsterdam: Rijksmuseum; and London: National Gallery, 1991.

Biagioli, Mario. Galileo, Courtier: The Practice of Science in the Culture of Absolutism. Chicago: University of Chicago Press, 1983.

Bourdieu, Pierre. Outline of a Theory of Practice. Translated by Richard Nice. Cambridge: Cambridge University Press, 1977.

- - Distinction: A Social Critique of the Judgment of Taste. Translated by Richard Nice. Cambridge, Mass.: Harvard University Press, 1984. 
- - . The Logic of Practice. Translated by Richard Nice. Stanford, Calif.: Stanford University Press, 1990.

- - . Practical Reason: On the Theory of Action. Translated by Randall Johnson. Stanford, Calif.: Stanford University Press, 1998.

Broekman, Inge. De rol van de schilderkunst in het leven van Constantijn Huygens, 1596-1687. Hilversum: Verloren, 2005.

Brown, Bill. “Thing Theory.” Critical Inquiry 28 (2001): 1-22.

Bruyn, Josua, et al., A Corpus of Rembrandt Paintings. Vol. 3. The Hague and Boston: M. Nijhoff Publishers, 1989.

van den Bussche, Emile. "Un évéque bibliophile. Notes sur la bibliothèque et le cabinet de gravures de Charles Vanden Bosch, neuvième évèque de Bruges; ses relations avec Elzévirs, Meyssens, etc." La Flandre: Revue des monuments d'histoire et d'antiquites 13 (1880): 345-68.

Carrier, James. Gifts and Commodities: Exchange and Western Capitalism Since 1700. London and New York: Routledge, 1995.

Clunas, Craig. Elegant Debts: The Social World of Wen Zhengming, 1470-1559. Honolulu: University of Hawaii Press, 2004.

Couvreur, Walter. "Danïel Seghers' inventaris van door hem geschilderde stukken." Gentse bijdragen tot de kunstgeschiedenis en de oudheidkunde 20 (1967): 87-158.

Crenshaw, Paul. Rembrandt's Bankruptcy: The Artist, His Patrons, and the Art Market in Seventeenth-Century Netherlands. Cambridge: Cambridge University Press, 2006.

Cropper, Elizabeth, and Charles Dempsey. Nicolas Poussin: Friendship and the Love of Painting. Princeton, N.J., Princeton University Press, 1996.

Davis, Natalie Zemon. "Beyond the Market: Books as Gifts in Sixteenth-Century France." Royal Historical Society Transactions 33 (1983): 69-88. doi:10.2307/3678990

- - . The Gift in Sixteenth-Century France. Madison, Wis.: University of Wisconsin Press, 2000.

Dickey, Stephanie. Rembrandt: Portraits in Print. Amsterdam and Philadelphia: John Benjamins, 2004.

Dudok van Heel, S. A. C. "Rembrandt van Rijn (1606-1669): A Changing Portrait of the Artist." In Rembrandt: The Master and His Workshop; Paintings, Christopher Brown, Jan Kelch, and Pieter van Thiel, 50-67. Exh. cat.. Berlin: Gemäldegalerie SMPK at the Altes Museum; Amsterdam: Rijksmuseum; and London: National Gallery, 1991. 
-_- “Jan Pietersz. Zomer (1641-1724): Makelaar in schilderijen (1690-1724)." Jaarboek Amstelodamum 69 (1977): 89-106.

van Eeghen, Isabella. "De familie de La Tombe en Rembrandt." Oud Holland 71 (1956): 43-49.

Ekkart, Rudolf, and E. Ornstein-van Slooten. Oog in oog met de modellen van Rembrandts portret-etsen (Face to Face with the Sitters of Rembrandt's Etched Portraits). Exh. cat. Amsterdam: Rembrandthuis, 1986.

van Gelder, Roelof, and Jaap van der Veen. "A Collector's Cabinet in the Breestraat: Rembrandt as a Lover of Art and Curiosities." In Rembrandt's Treasures, Bob van den Boogert, et al., 33-89. Exh. cat. Amsterdam: Rembrandthuis, 1999.

Gell, Alfred. Art and Agency: An Anthropological Theory. Oxford and New York: Clarendon Press, 1998.

Gerson, Horst. Seven Letters by Rembrandt. Translated by Yda D. Ovink. The Hague: L. J. C. Boucher, 1961.

Godelier, Maurice. The Enigma of the Gift. Translated by Nora Scott. Chicago: University of Chicago Press, 1999.

Hennion, Antoine. "Pragmatics of Taste." In The Blackwell Companion to the Sociology of Culture, edited by Mark D. Jacobs and Nancy Weiss Hanrahan, 131-44. Malden, Mass.: Blackwell, 2005. doi:10.1002/9780470996744.ch9

Hinterding, Erik. Rembrandt as an Etcher: The Practice of Production and Distribution. Translated by Michael Hoyle. Studies in Prints and Printmaking 6. Ouderkerk aan den Ijssel: Sound and Vision, 2006.

Hinterding, Erik, Ger Luijten, and Martin Royalton-Kisch. Rembrandt the Printmaker. Exh. cat. London: British Museum; and Amsterdam: Rijksmuseum, 2000.

Honig, Elizabeth Alice. "The Space of Gender in Seventeenth-Century Dutch Painting." In Looking at Seventeenth-Century Dutch Painting: Realism Reconsidered, edited by Wayne Franits, 186-201. Cambridge: Cambridge University Press, 1997.

Hofstede de Groot, Cornelis. Die Urkunden über Rembrandt, 1575-1721. The Hague: M. Nijhoff, 1906.

Janssen, Geert. Princely Power in the Dutch Republic: Patronage and William Frederick of Nassau. Translated by J. C. Grayson. Manchester, England, and New York: Manchester University Press, 2008. 
Jardine, Lisa. Worldly Goods: A New History of the Renaissance. New York and London: W. W. Norton, 1998.

Kettering, Sharon. "Gift-Giving and Patronage in Early Modern France." French History 2 (1988): 419-47. doi:10.1093/fh/2.2.131

- - . Patrons, Brokers, and Clients in Seventeenth-Century France. New York: Oxford University Press, 1986.

Koolhaas, Rem and Bruce Mau. Small, Medium, Large, Extra-Large: Office for Metropolitan Architecture. Edited by Jennifer Sigler. New York: Monacelli Press, 1995.

Lammertse, Friso, and Jaap van der Veen. Uylenburgh and Son: Art and Commerce from Rembrandt to De Lairesse, 1625-1675. Exh. cat. London: Dulwich Picture Gallery, and Amsterdam: Rembrandthuis, 2006.

Latour, Bruno. "The Berlin Key or How to Do Words with Things." In Matter, Materiality, and Modern Culture, edited by P. M. Graves-Brown and translated by Lydia Davis, 10-21. London and New York: Routledge, 2000.

- - Reassembling the Social: An Introduction to Actor-Network-Theory. Oxford and New York: Oxford University Press, 2007.

Lévi-Strauss, Claude. The Elementary Structures of Kinship. Edited by Rodney Needham and translated by James Harle Bell and John Richard von Sturmer. Boston, Beacon Press, 1969.

Luijten, Ger. "Rembrandt the Printmaker: The Shaping of an Oeuvre." In Rembrandt the Printmaker, Erik Hinterding, Ger Luijten, and Martin Royalton-Kisch, 11-22. Exh. cat. London: British Museum; and Amsterdam: Rijksmuseum, 2000.

Magnani, Lauro. "1666: Een onbekende opdracht uit Genua voor Rembrandt." Kroniek van het Rembrandthuis (2007): 2-17.

Malvasia, Carlo Cesare. The Life of Guido Reni. Translated and with an introduction by Catherine Enggass and Robert Enggass. University Park, Pa., and London: Pennsylvania State University Press, 1980.

Mauss, Marcel. The Gift: The Form and Reason for Exchange in Archaic Societies. Translated by W. D. Halls, with a foreword by Mary Douglas. New York and London: Routledge, 2000.

Nagel, Alexander. "Art as Gift: Liberal Art and Religious Reform in the Renaissance." In Negotiating the Gift: Pre-Modern Figurations of Exchange, edited by Gadi Algazi, Valentin Groebner, and Bernhard Juseen, 319-60. Philadelphia: Vandenhoeck and Ruprecht, 2003. 
_—_. “Gifts for Michelangelo and Vittoria Colonna.” Art Bulletin 79 (1997): 64768. doi:10.2307/3046280

Osborne, Robin, and Jeremy Tanner, eds. Art's Agency and Art History. Oxford: Blackwell, 2007.

Osteen, Mark. The Question of the Gift: Essays Across Disciplines. London and New York: Routledge, 2002.

Van der Ploeg, Peter, and Carola Vermeeren. "From the 'Sea Prince's' Monies: The Stadhouder's Art Collection." In Princely Patrons: The Collection of Frederik Hendrik of Orange and Amalia von Solms in The Hague, Peter van der Ploeg and Carola Vermeeren, et al., 34-60. Exh. cat. The Hague: Mauritshuis, 1997.

Van der Ploeg, Peter, and Carola Vermeeren, et al. Princely Patrons: The Collection of Frederik Hendrik of Orange and Amalia von Solms in The Hague. Exh. cat. The Hague: Mauritshuis, 1997.

Rassieur, Thomas. "Looking Over Rembrandt's Shoulder: The Printmaker at Work." In Rembrandt's Journey: Painter, Draftsman, Etcher, Clifford Ackley, et al., 45-60. Exh. cat. Boston: Museum of Fine Arts; and Chicago: Art Institute of Chicago, 2003.

Sahlins, Marshall. Stone Age Economics. Chicago: Aldine-Atherton, 1972.

Schrift, Alan, ed. The Logic of the Gift: Toward an Ethic of Generosity. New York: Routledge, 1997. Schwartz, Gary. Rembrandt: His Life, His Paintings. New York: Viking, 1985.

-——. Rembrandt's Universe: His Art, His Life; His World. London: Thames and Hudson, 2006.

Six, Jan. "Iets over Rembrandt." Oud Holland 11 (1893): 154-61.

-------. “Rembrandt's voorbreiding van de etsen van Jan Six en Abraham Francen." Onze Kunst 14 (1908): 53-65.

Sluijter, Eric Jan. "Determining Value on the Art Market in the Golden Age: An Introduction." In Art Market and Connoisseurship: A Closer Look at Paintings by Rembrandt, Rubens, and Their Contemporaries, edited by Anna Tummers and Koenraad Jonckheere, 7-28. Amsterdam: Amsterdam University Press, 2008.

Spear, Richard. The 'Divine Guido': Religion, Sex, Money and Art in the World of Guido Reni. New Haven, Conn.: Yale University Press, 1997.

Strathern, Marilyn. The Gender of the Gift: Problems with Women and Problems with Society in Melanesia. Berkeley, Calif.: University of California Press, 1988.

Strauss, Walter, and Marjon van der Meulen, with the assistance of S. A. C. Dudok van Heel and 
P. J. M. de Baar. The Rembrandt Documents. New York: Abaris Books, 1979.

Thoen, Irma. Strategic Affection? Gift Exchange in Seventeenth-Century Holland. Amsterdam: Amsterdam University Press, 2007.

van der Veen, Jaap. “The Network of Collectors Around Rembrandt." In Rembrandt's Treasures, Bob van den Boogert, et al., 141-45. Exh. cat. Amsterdam: Rembrandthuis, 1999.

-_- "Patronage for Lievens' Portraits and History Pieces, 1644-1674." In Jan Lievens: A Dutch Master Reconsidered, Arthur K. Wheelock Jr., et al., 30-39. Exh. cat. Washington, D.C.: National Gallery of Art; Milwaukee: Milwaukee Art Museum; and Amsterdam: Rembrandthuis, 2008.

Vandevelde, Antoon. Gifts and Interests. Louvain: Peeters, 2000.

van Tol, D. "Een portret van dr. Arnout Tholinx (1607-1679)." Jaarboek van het Centraal Bureau voor Genealogie en het Ikonografisch Bureau 37 (1983): 139-50.

Warwick, Genevieve. "Gift Exchange and Art Collecting: Padre Sebastiano Resta’s Drawing Albums." Art Bulletin 79 (1997): 630-46. doi:10.2307/3046279

Weiner, Annette. Inalienable Possessions: The Paradox of Keeping-While-Giving. Berkeley, Calif.: University of California Press, 1992.

Westermann, Mariët. Rembrandt. London: Phaidon, 2000.

White, Christopher, and Karel G. Boon. Rembrandt's Etchings: An Illustrated Critical Catalogue. Vol. 1. Amsterdam: M. Hertzberger, 1969.

Williams, Julia Lloyd, et al. Rembrandt's Women. Exh. cat. Edinburgh: National Gallery of Scotland; and London: National Gallery, 2001.

Zell, Michael. “The Gift Between Friends: Rembrandt's Art in the Network of His Patronal and Social Relations." In Rethinking Rembrandt, edited by Alan Chong and Michael Zell, 173-93. Zwolle: Waanders, 2002.

Recommended Citation:

Michael Zell, "Rembrandt's Gifts: A Case Study of Actor-Network-Theory," JHNA 3:2 (Summer 2011), D0I: 10.5092/ jhna.2011.3.2.2 